\title{
Deoxygenative gem-difluoroolefination of carbonyl compounds with (chlorodifluoromethyl)trimethyl- silane and triphenylphosphine
}

\author{
Fei Wang, Lingchun Li, Chuanfa $\mathrm{Ni}$ and Jinbo $\mathrm{Hu}^{*}$
}

Open Access

\author{
Full Research Paper \\ Address: \\ Key Laboratory of Organofluorine Chemistry, Shanghai Institute of \\ Organic Chemistry, Chinese Academy of Sciences, 345 Ling-Ling \\ Road, Shanghai 200032, China \\ Email: \\ Jinbo Hu* - jinbohu@sioc.ac.cn \\ * Corresponding author \\ Keywords: \\ (chlorodifluoromethyl)trimethylsilane; difluorocarbene; \\ gem-difluoroolefin; organo-fluorine; Wittig reaction; ylide
}

\begin{abstract}
Beilstein J. Org. Chem. 2014, 10, 344-351.
\end{abstract}
doi:10.3762/bjoc. 10.32

Received: 16 September 2013

Accepted: 14 January 2014

Published: 06 February 2014

This article is part of the Thematic Series "Organo-fluorine chemistry III".

Guest Editor: D. O'Hagan

(C) 2014 Wang et al; licensee Beilstein-Institut. License and terms: see end of document.

\begin{abstract}
Background: 1,1-Difluoroalkenes cannot only be used as valuable precursors for organic synthesis, but also act as bioisosteres for enzyme inhibitors. Among various methods for their preparation, the carbonyl olefination with difluoromethylene phosphonium ylide represents one of the most straightforward methods.

Results: The combination of (chlorodifluoromethyl)trimethylsilane $\left(\mathrm{TMSCF}_{2} \mathrm{Cl}\right)$ and triphenylphosphine $\left(\mathrm{PPh}_{3}\right)$ can be used for the synthesis of gem-difluoroolefins from carbonyl compounds. Comparative experiments demonstrate that $\mathrm{TMSCF}_{2} \mathrm{Cl}_{\text {is }} \mathrm{superior}$ to (bromodifluoromethyl)trimethylsilane $\left(\mathrm{TMSCF}_{2} \mathrm{Br}\right)$ and (trifluoromethyl)trimethylsilane $\left(\mathrm{TMSCF}_{3}\right)$ in this reaction.
\end{abstract}

Conclusion: Similar to many other Wittig-type gem-difluoroolefination reactions in the presence of $\mathrm{PPh}_{3}$, the reaction of $\mathrm{TMSCF}_{2} \mathrm{Cl}$ with aldehydes and activated ketones is effective.

\section{Introduction}

The synthesis and application of selectively fluorinated organic molecules have attracted much interest from both organic chemists and biochemists because fluorine can endow these molecules with unique chemical, biological and physical properties [1-3]. 1,1-Difluoroalkenes have been frequently used in the design of potential enzyme inhibitors [4-6], since difluoro- methylene functionality $\left(\mathrm{CF}_{2}\right)$ is known to be isosteric and isopolar to an oxygen atom [7-9], and the gem-difluorovinyl functionality is believed to be a bioisostere for a carbonyl group [10]. More commonly, 1,1-difluoroalkenes, which are highly electrophilic towards many nucleophiles at the terminal difluoromethylene carbon [11], are used as valuable precursors 
of di- and trifluoromethyl compounds $[10,12]$, monofluoroalkenes [13], monofluorinated heterocycles [14,15], carboxylic acids and esters [16]. Consequently, these relevant applications of 1,1-difluoroalkenes have led to many efforts to develop gemdifluoroolefination methods including $\beta$-elimination of functionalized difluoromethyl compounds, transition metal catalysed coupling reactions with gem-difluorovinylation reagents, and deoxygenative gem-difluoroolefination of carbonyl compounds $[17,18]$. Among these methods, the latter one has been studied with several named reactions, for example Wittig, Horner-Wadsworth-Emmons, and Julia-Kocienski reactions.

In the Wittig gem-difluoroolefination, the reaction is believed to proceed via an undetected difluoromethylene phosphonium ylide, which can be generated in situ either by the transformation of a difluorinated phosphonium salt or by the reaction between difluorocarbene (: $\left.\mathrm{CF}_{2}\right)$ and a phosphine (Scheme 1) [19-26]. In 1964, Fuqua and co-workers first reported the difluoromethylenation of aldehydes by using $\mathrm{ClCF}_{2} \mathrm{CO}_{2} \mathrm{Na} / \mathrm{PPh}_{3}$ [19]. In 1967, Burton and Herkes suggested that the ylide intermediate involved in the olefination process was more likely to be formed by the decarboxylation of a difluorinated phosphonium salt rather than the combination of : $\mathrm{CF}_{2}$ and a phosphine (Scheme 1, reaction 1) [20]. Their suggestion is based on the accelerating effect of $\mathrm{PPh}_{3}$ on the thermal decomposition of $\mathrm{ClCF}_{2} \mathrm{CO}_{2} \mathrm{Na}$ and the unsuccessful capture of $: \mathrm{CF}_{2}$ with an alkene or alcohol during the olefination reaction [20]. Very recently, the successful preparation of (triphenylphosphonio)difluoroacetate $\left(\mathrm{Ph}_{3} \mathrm{P}^{+} \mathrm{CF}_{2} \mathrm{CO}_{2}{ }^{-}\right)$and its application in carbonyl gem-difluoroolefination by Xiao and co-workers [21] finally confirmed the mechanism proposed by Burton and others $[19,20]$. Burton and co-workers also developed another difluorocarbene-free approach using a 1:2 mixture of $\mathrm{CF}_{2} \mathrm{Br}_{2}$ and $\mathrm{PPh}_{3}$ or $\mathrm{P}\left(\mathrm{NMe}_{2}\right)_{3}$ to prepare the ylide intermediate (Scheme 1, reaction 2) [22,23]. Although the difluorocarbene/ phosphine procedure for Wittig olefination has been put forward by Fuqua et al. as early as 1964 [19], the formation of difluoromethylene phosphonium ylide in such a way is quite rare [24-26]. Established examples include using bis(trifluoromethyl)mercury $\left(\mathrm{Hg}\left(\mathrm{CF}_{3}\right)_{2}\right)$ under the promotion of $\mathrm{NaI}$ (Scheme 1, reaction 3) [24] and using methyl 2,2-difluoro-2(fluorosulfonyl)acetate (MDFA) under the promotion of KI (Scheme 1, reaction 4) [25].

Our group has focused on the development and application of new difluorocarbene reagents [27-34]. The Prakash group and we have identified that (halodifluoromethyl)trimethylsilanes ( $\mathrm{TMSCF}_{2} \mathrm{X}, \mathrm{X}=\mathrm{F}, \mathrm{Cl}$, and $\mathrm{Br}$ ) could serve as difluorocarbene sources under the activation of proper halide initiators or alkaline bases (Scheme 2) [31-34]. Recently, we have developed a relatively environmentally benign method to prepare $\mathrm{TMSCF}_{2} \mathrm{Br}$, which can be used as a general carbene source for

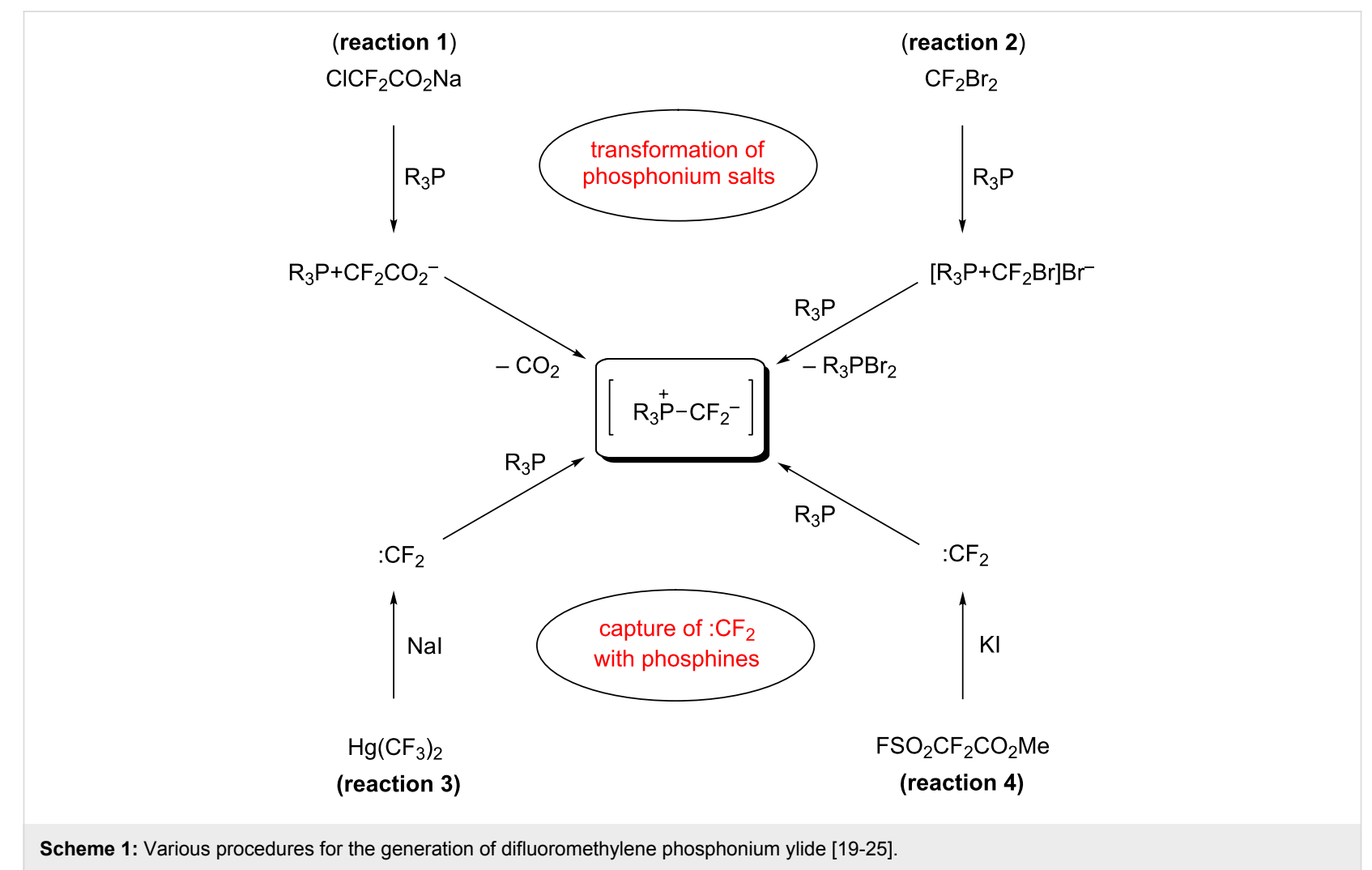




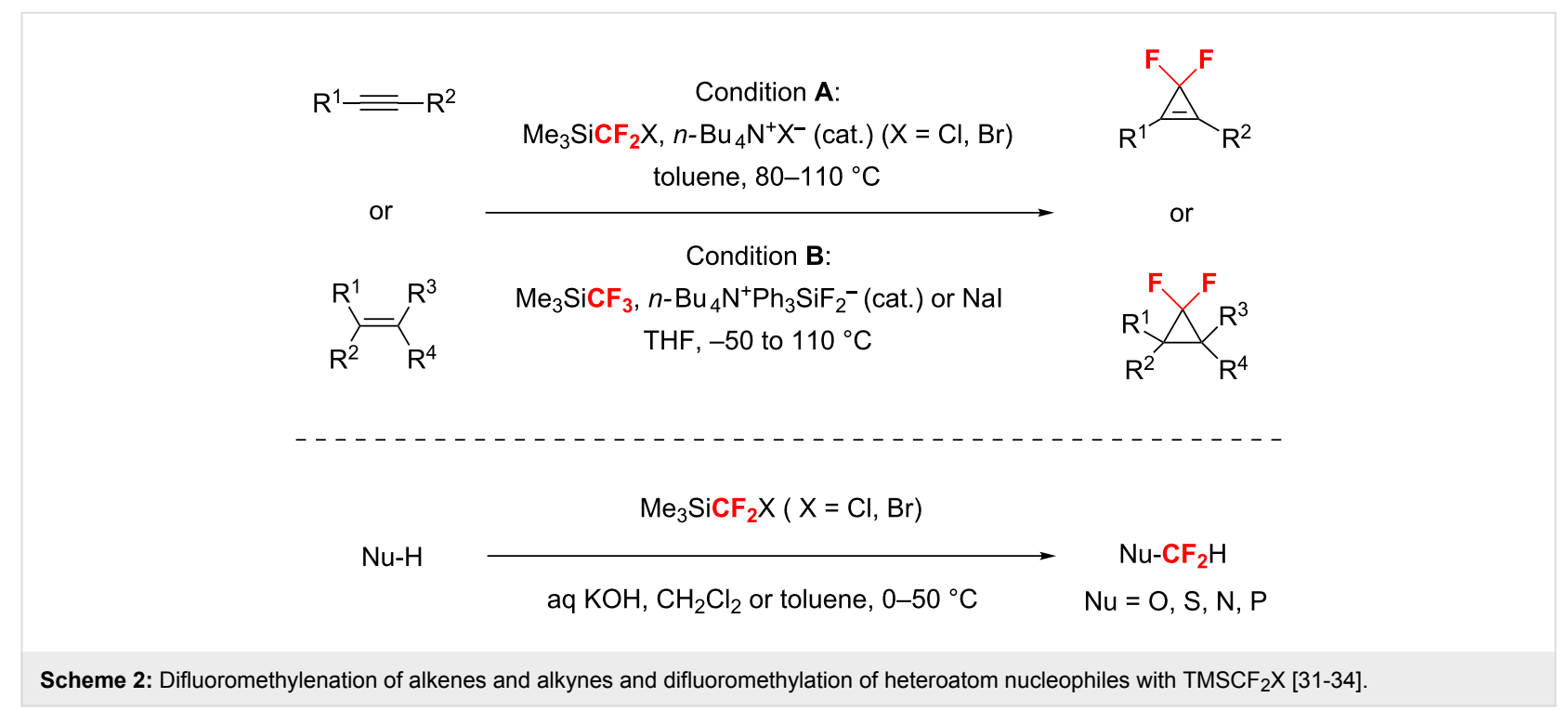

the difluoromethylenation of alkynes and alkenes and difluoromethylation of heteroatom nucleophiles [34]. In this paper, the novel preparation of $\mathrm{TMSCF}_{2} \mathrm{Cl}$ from $\mathrm{TMSCF}_{2} \mathrm{Br}$ and the application of the former in deoxygenative gem-difluoroolefination of carbonyl compounds via Wittig-type reaction are reported.

\section{Results and Discussion}

(Halodifluoromethyl)trimethylsilanes including $\mathrm{TMSCF}_{3}$ (Ruppert-Prakash reagent), $\mathrm{TMSCF}_{2} \mathrm{Cl}$, and $\mathrm{TMSCF}_{2} \mathrm{Br}$ are initially prepared by reductive silylation of ozone-depletingsubstances bromotrifluoromethane $\left(\mathrm{CF}_{3} \mathrm{Br}\right)$ [35], bromochlorodifluoromethane $\left(\mathrm{CF}_{2} \mathrm{BrCl}\right)$ [36,37], and dibromodifluoromethane $\left(\mathrm{CF}_{2} \mathrm{Br}_{2}\right)[36,37]$ with chlorotrimethylsilane (TMSCl). In recent years, Prakash and co-workers have discovered two Freon-free methods for the synthesis of $\mathrm{TMSCF}_{3}$ from fluoroform $\left(\mathrm{CF}_{3} \mathrm{H}\right)$, which paved the way for the synthetic applications of $\mathrm{TMSCF}_{3}[38,39]$. Moreover, the preparation of $\mathrm{TMSCF}_{2} \mathrm{Br}$ either by fluoro-bromo exchange reaction of $\mathrm{TMSCF}_{3}[34]$ or by bromination of $\mathrm{TMSCF}_{2} \mathrm{H}[34,40]$ has also been disclosed. To obtain $\mathrm{TMSCF}_{2} \mathrm{Cl}$, we tried the halogen exchange reaction of $\mathrm{TMSCF}_{2} \mathrm{Br}$. When a 1:10 mixture of $\mathrm{TMSCF}_{2} \mathrm{Br}$ and $\mathrm{TMSCl}$ was heated in neat in the presence of $5 \mathrm{~mol} \%$ of tetrabutylammonium chloride (TBAC) for 2 hours, ${ }^{19} \mathrm{~F}$ NMR spectroscopy analysis showed that the ratio of $\mathrm{TMSCF}_{2} \mathrm{Cl}$ to $\mathrm{TMSCF}_{2} \mathrm{Br}$ was $2.3: 1$, and prolonging reaction time could not improve the ratio. In view of the difficulty in separating $\mathrm{TMSCF}_{2} \mathrm{Cl}$ from the reaction mixture because of the approximate boiling points of $\mathrm{TMSCF}_{2} \mathrm{Cl}\left(\sim 85^{\circ} \mathrm{C}\right)[36,37]$ and $\mathrm{TMSCF}_{2} \mathrm{Br}\left(\sim 105^{\circ} \mathrm{C}\right)[36,37]$, other chloride sources were tried to achieve a full conversion of $\mathrm{TMSCF}_{2} \mathrm{Br}$. Gratifyingly, when the reaction was performed in benzonitrile $\left(\mathrm{bp} \sim 190{ }^{\circ} \mathrm{C}\right.$ ) at $80^{\circ} \mathrm{C}$ using a slight excess of silver chloride under the catalysis of TBAC, a full conversion of $\mathrm{TMSCF}_{2} \mathrm{Br}$ afforded $\mathrm{TMSCF}_{2} \mathrm{Cl}$ in $54 \%$ yield. Lowering the temperature to room temperature (rt) could improve the yield to $80 \%$ (Scheme 3 ). It is believed that the lower solubility of silver bromide than silver chloride in benzonitrile provides the driving force for this bromo-chloro exchange reaction.

$\mathrm{Me}_{3} \mathrm{SiCF}_{2} \mathrm{Br}+\mathrm{AgCl}$
$\begin{aligned} & 1.0 \text { equiv } \\ & \text { Scheme 3: Bromo-chloro exchange reaction using AgCl. }\end{aligned}$

At first, the olefination of 1-naphthaldehyde (1a) or benzaldehyde (1b) by using the combination of $\mathrm{TMSCF}_{2} \mathrm{Cl}$ and $\mathrm{PPh}_{3}$ was tried. Conceiving that the chloride ion might be necessary to promote the decomposition of $\mathrm{TMSCF}_{2} \mathrm{Cl}$ to release $\mathrm{CF}_{2}$ as reported, a catalytic amount of TBAC was used as the initiator. After heating a reaction mixture of aldehyde 1a, $\mathrm{TMSCF}_{2} \mathrm{Cl}$, $\mathrm{PPh}_{3}$, and TBAC in THF at $100{ }^{\circ} \mathrm{C}$ for $8 \mathrm{~h},{ }^{19} \mathrm{~F}$ NMR spectroscopy analysis showed that difluorinated alkene 2a was formed in $69 \%$ yield (Table 1, entry 1). Surprisingly, it was found that in the absence of TBAC, $\mathrm{PPh}_{3}$ could be used both to promote the fragmentation of $\mathrm{TMSCF}_{2} \mathrm{Cl}$ and combine with the generated : $\mathrm{CF}_{2}$ (Table 1, entry 2). A rough comparison of the reaction temperatures showed that a lower temperature (rt) is detrimental to the olefination process, although the decomposition of $\mathrm{TMSCF}_{2} \mathrm{Cl}$ could occur to some extent (Table 1, entries 2 and 3$)$.

Subsequently, the olefination of aldehyde $\mathbf{1 b}$ with $\mathrm{TMSCF}_{2} \mathrm{Br}$ was examined. Unfortunately, the full consumption of 
Table 1: Condition screening of gem-difluoroolefination with $\mathrm{TMSCF}_{2} \mathrm{X}$.

\begin{tabular}{|c|c|c|c|c|c|c|c|c|}
\hline & & $\begin{array}{c}\mathrm{Ar}-\mathrm{CHO} \\
\mathbf{1} \\
1.0 \text { equiv }\end{array}$ & + & $\begin{array}{l}\text { TMSCF }_{2} \mathrm{X}+ \\
3.0 \text { equiv }\end{array}$ & $\begin{array}{c}\mathrm{PPh}_{3} \\
3.0 \text { equiv }\end{array}$ & $\mathrm{p}, t$ & $\mathrm{Ar}_{2}^{\mathrm{F}}$ & \\
\hline Entry ${ }^{a}$ & $\mathrm{Ar}$ & $x$ & & Initiator & Temp $\left({ }^{\circ} \mathrm{C}\right)$ & $t(\mathrm{~h})$ & Conversion (\%) & Yield $(\%)^{b}$ \\
\hline 1 & 1-naphthyl & $\mathrm{Cl}$ & & TBAC (3 mol \%) & 100 & 8 & 100 & 69 \\
\hline 2 & 1-naphthyl & $\mathrm{Cl}$ & & none & 70 & 10 & 100 & $59^{c}$ \\
\hline 3 & $\mathrm{Ph}$ & $\mathrm{Cl}$ & & none & $\mathrm{rt}$ & 4 & 35 & 0 \\
\hline 4 & $\mathrm{Ph}$ & $\mathrm{Br}$ & & none & 70 & 10 & 100 & 0 \\
\hline 5 & $\mathrm{Ph}$ & $\mathrm{F}$ & & Nal (0.6 equiv) & 70 & 10 & $<5$ & 0 \\
\hline 6 & $\mathrm{Ph}$ & $\mathrm{F}$ & & Nal (6.0 equiv) & 110 & 10 & $<5$ & 0 \\
\hline
\end{tabular}

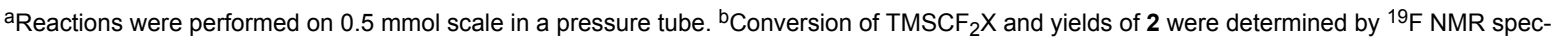
troscopy using $\mathrm{PhCF}_{3}$ as an internal standard. CIsolated yield of $\mathbf{2 a}$.

$\mathrm{TMSCF}_{2} \mathrm{Br}$ did not afford any difluoroolefin $\mathbf{2 b}$ (Table 1, entry 4). As determined by ${ }^{19} \mathrm{~F}$ NMR, besides the side product (difluoromethyl)triphenylphosponium bromide $(\delta-127.9$, dd, ${ }^{3} J_{\mathrm{P}-\mathrm{F}}=80 \mathrm{~Hz},{ }^{2} J_{\mathrm{F}-\mathrm{H}}=47 \mathrm{~Hz}$ ) as reported in the Wittig olefination with $\mathrm{FSO}_{2} \mathrm{CF}_{2} \mathrm{CO}_{2} \mathrm{Me}$ [25], a new product which was assigned as difluorinated phosphonium salt $\mathbf{4}(\delta-88.8$, ddd, ${ }^{2} J_{\mathrm{F}-\mathrm{F}}=298 \mathrm{~Hz},{ }^{3} J_{\mathrm{P}-\mathrm{F}}=97 \mathrm{~Hz},{ }^{3} J_{\mathrm{F}-\mathrm{H}}=3.3 \mathrm{~Hz}, 1 \mathrm{~F} ; \delta-106.6$, $\left.\mathrm{ddd},{ }^{2} J_{\mathrm{F}-\mathrm{F}}=298 \mathrm{~Hz},{ }^{3} J_{\mathrm{P}-\mathrm{F}}=101 \mathrm{~Hz},{ }^{3} J_{\mathrm{F}-\mathrm{H}}=24 \mathrm{~Hz}, 1 \mathrm{~F}\right)$ was detected as the major product (for details, see Supporting Information File 1). The formation of $\mathbf{4}$ is supposed to arise from a ready silylation of the addition intermediate betaine 3 by TMSBr. When $\mathrm{TMSCF}_{2} \mathrm{Cl}$ was used, $\mathrm{TMSCl}$ is not reactive enough to trap the betaine $\mathbf{3}$, thus the oxaphosphetane $\mathbf{5}$ could be formed to give olefins and triphenylphosphine oxide (Scheme 4).

Finally, the olefination of aldehyde $\mathbf{1 b}$ with $\mathrm{TMSCF}_{3}$ as the difluoromethylene source was tested. The results showed that no desired reaction took place when $\mathrm{PPh}_{3}$ and either substoichiometric or stoichiometric amounts of $\mathrm{NaI}$ were used

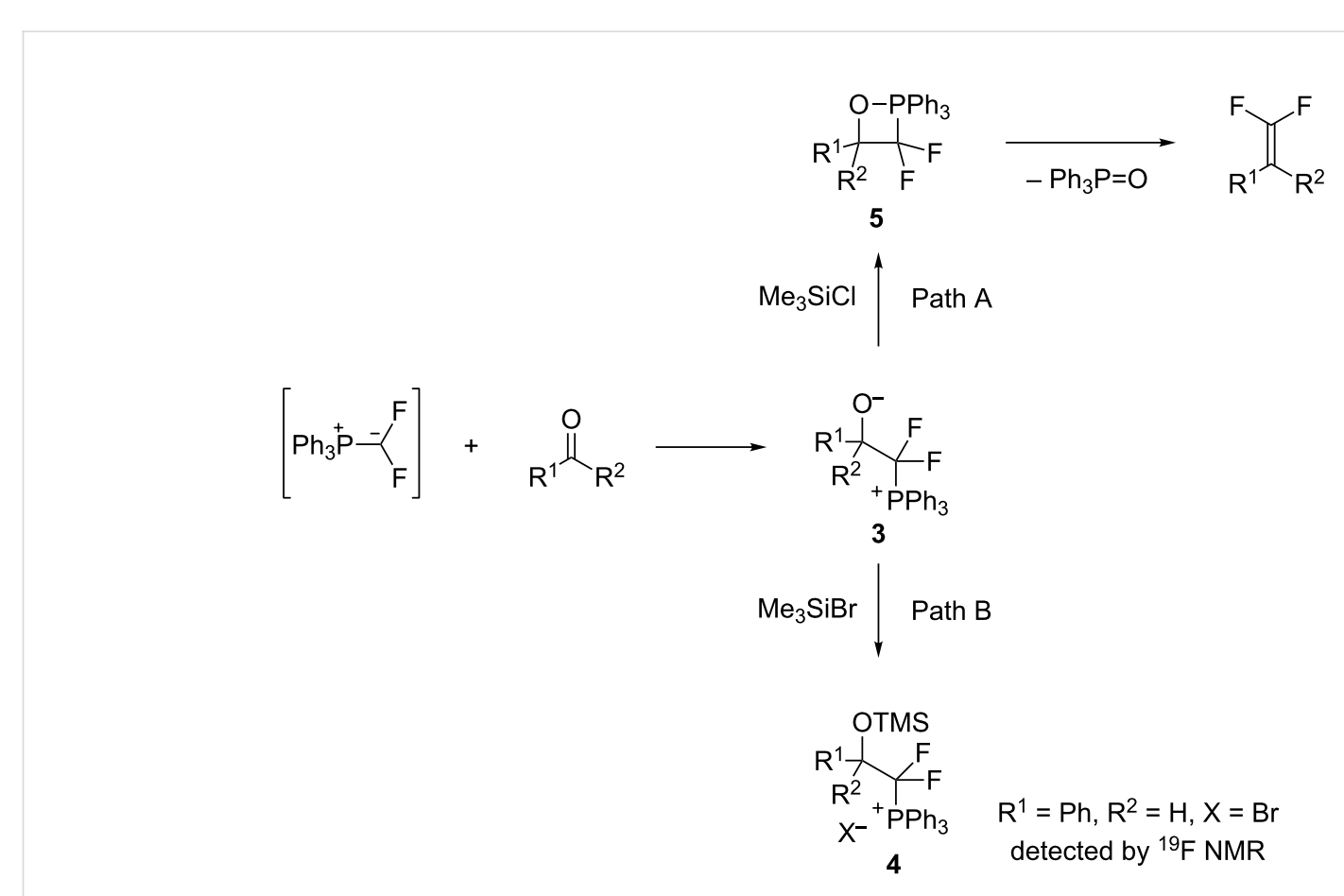


(Table 1, entries 5 and 6). Although it has been known that $\mathrm{TMSCF}_{3}$ can be used in the difluoromethylenation of alkenes and alkynes initiated by $\mathrm{NaI}$ [33], we could not give a reasonable explanation for the failure of the current reaction.

Using the conditions shown in Table 1, entry 2 as standard, the olefination of aldehydes with $\mathrm{TMSCF}_{2} \mathrm{Cl}$ was investigated. As shown in Figure 1, a variety of structurally diverse aromatic aldehydes were successfully converted into gem-difluoro- alkenes $\mathbf{2 a}-\mathbf{g}$ in moderate to good yields. It should be mentioned that the aromatic aldehydes with substituents such as $t$-butylthio, methoxy, and bromo groups on the phenyl ring showed similar reactivity. Moreover, this approach is also amenable to enolizable aldehydes, for example, gem-difluoroolefin $\mathbf{2 h}$ could be obtained in $47 \%$ yield. Although a non-activated ketone such as acetophenone is unreactive under similar conditions, activated ketones could undergo this Wittig olefination reaction. Representative results for the olefination at a<smiles>FC(F)=Cc1cccc2ccccc12</smiles>

2a $(59 \%)^{a}$<smiles>CC(C)(C)c1ccccc1C=C(F)F</smiles>

2 e $(61 \%)^{a}$<smiles>FC(F)=Cc1ccccc1</smiles>

$2 \mathrm{~b}(42 \%)^{\mathrm{b}}$<smiles>COc1ccc(C=C(F)F)cc1OC</smiles>

$2 \mathbf{f}(55 \%)^{\mathrm{a}}$<smiles>FC(F)=Cc1ccc2ccccc2c1</smiles>

$2 c(51 \%)^{a}$<smiles>FC(F)=Cc1ccc(Br)cc1</smiles>

$2 \mathrm{~g}(53 \%)^{\mathrm{a}}$<smiles>FC(F)=Cc1ccc(-c2ccccc2)cc1</smiles>

$2 d(46 \%)^{a}$

2h $(47 \%)^{a}$

Figure 1: gem-Difluoroolefination of aldehydes. Reactions were performed on $0.5 \mathrm{mmol}$ scale in a pressure tube. ${ }^{\mathrm{a}}$ Isolated yield. ${ }^{\mathrm{b}}$ Yield was determined by ${ }^{19} \mathrm{~F}$ NMR spectroscopy using $\mathrm{PhCF}_{3}$ as an internal standard.

$$
\begin{aligned}
& \stackrel{\mathrm{R}}{\mathrm{O}}_{\mathrm{CF}_{2} \mathrm{X}}+\mathrm{TMSCF}_{2} \mathrm{Cl}+\mathrm{PPh}_{3} \underset{80^{\circ} \mathrm{C}, 10 \mathrm{~h}}{\mathrm{THF}} \\
& 6(X=F, C l) \\
& 3.0 \text { equiv } \quad 3.0 \text { equiv }
\end{aligned}
$$<smiles>FC(F)=C(c1ccccc1)C(F)(F)F</smiles>

$7 a(58 \%)^{a}$<smiles>FC(F)=C(c1ccccc1)C(F)(Cl)Cl</smiles>

7 e $(58 \%)^{\mathrm{a}}$<smiles>Cc1ccc(C(=C(F)F)C(F)(F)F)cc1</smiles>

7b $(77 \%)^{b}$<smiles>Cc1ccc(C(=C(F)F)C(F)(Cl)Cl)cc1</smiles>

7f $(79 \%)^{b}$<smiles>COc1ccc(C(=C(F)F)C(F)(F)F)cc1</smiles>

$7 \mathrm{c}(70 \%)^{\mathrm{b}}$<smiles>FC(F)=C(c1ccc(Cl)cc1)C(Cl)(Cl)Cl</smiles>

$7 g(66 \%)^{b}$ 
slightly elevated temperature $\left(80^{\circ} \mathrm{C}\right)$ are shown in Figure 2. A range of aryl trifluoromethyl $(\mathbf{6 a}-\mathbf{d})$ and chlorodifluoromethyl aromatic ketones $(\mathbf{6 e}-\mathbf{g})$ were readily difluoromethylenated to give the corresponding olefins $(\mathbf{7 a}-\mathbf{g})$ in moderate to good yields. It should be mentioned that in all cases, the formation of gem-difluoroolefins was accompanied by the formation of $\mathrm{Ph}_{3} \mathrm{PF}_{2}\left(\delta-41.2, \mathrm{~d},{ }^{1} J_{\mathrm{P}-\mathrm{F}}=668 \mathrm{~Hz}\right)[25], \mathrm{HCF}_{2} \mathrm{Cl}$, fluorotrimethylsilane, and some unidentified byproducts in variable yields (for details, see Supporting Information File 1).

As previously reported, the key mechanistic issue of this Wittigtype reaction is the formation of the presumed difluoromethylene triphenylphosphonium ylide [19-25]. Initially it was speculated that it were trace amounts of nucleophilic impurities (such as chloride ions) that initiated the fragmentation of TMSCF $2 \mathrm{Cl}$ to release : $\mathrm{CF}_{2}$ [31], which combined with $\mathrm{PPh}_{3}$ to form the ylide. However, the experiment at room temperature showed that $\mathrm{PPh}_{3}$ could significantly accelerate the decomposition of $\mathrm{TMSCF}_{2} \mathrm{Cl}$, which indicated that $\mathrm{PPh}_{3}$ should have participated in the activation of $\mathrm{TMSCF}_{2} \mathrm{Cl}$. Consequently, two plausible mechanisms are proposed (Scheme 5): one is the initial activation of the $\mathrm{C}-\mathrm{Si}$ bond by $\mathrm{PPh}_{3}$ (Path A), the other is the initial activation of the $\mathrm{C}-\mathrm{Cl}$ bond by $\mathrm{PPh}_{3}$ (Path $\left.\mathrm{B}\right)$. In Path
$\mathrm{A}, \mathrm{PPh}_{3}$ firstly coordinates the silicon atom of $\mathrm{TMSCF}_{2} \mathrm{Cl}$ to form activated penta-coordinated silicon species 8 [41] and activates both the $\mathrm{C}-\mathrm{Si}$ and the $\mathrm{C}-\mathrm{Cl}$ bond. Next, the release of $\mathrm{CF}_{2}$ leads to silylphosphonium salt 9. Finally, the fragmentation of 9 occurs to give TMSCl with regeneration of $\mathrm{PPh}_{3}$; meanwhile, the trapping of : $\mathrm{CF}_{2}$ by $\mathrm{PPh}_{3}$ gives the ylide. In Path $\mathrm{B}$, a phosphonium salt 10, which is formed via a single-electron transfer (SET) mechanism, undergoes a chloride ion-promoted desilylation reaction to afford $\mathrm{Ph}_{3} \mathrm{P}=\mathrm{CF}_{2}[42,43]$. However, we could not rule out the possibility of chloride ion-activation in these processes due to the involvement of intermediates $\mathbf{9}$ and $\mathbf{1 0}$ in the proposed mechanisms.

\section{Conclusion}

In conclusion, a robust difluoromethylenation reagent (chlorodifluoromethyl)trimethylsilane $\left(\mathrm{TMSCF}_{2} \mathrm{Cl}\right)$ has been prepared via a relatively environmentally benign method and has been successfully used in the Wittig difluoroolefination. Similar as many other Wittig-type gem-difluoroolefination reactions in the presence of $\mathrm{PPh}_{3}$, the reaction of $\mathrm{TMSCF}_{2} \mathrm{Cl}$ with aldehydes and activated ketones is effective. Comparative reactions with $\mathrm{TMSCF}_{2} \mathrm{Br}$ and $\mathrm{TMSCF}_{3}$ under similar conditions failed to give the gem-difluorinated olefins, which indicate that the halo-

\section{Path A:}

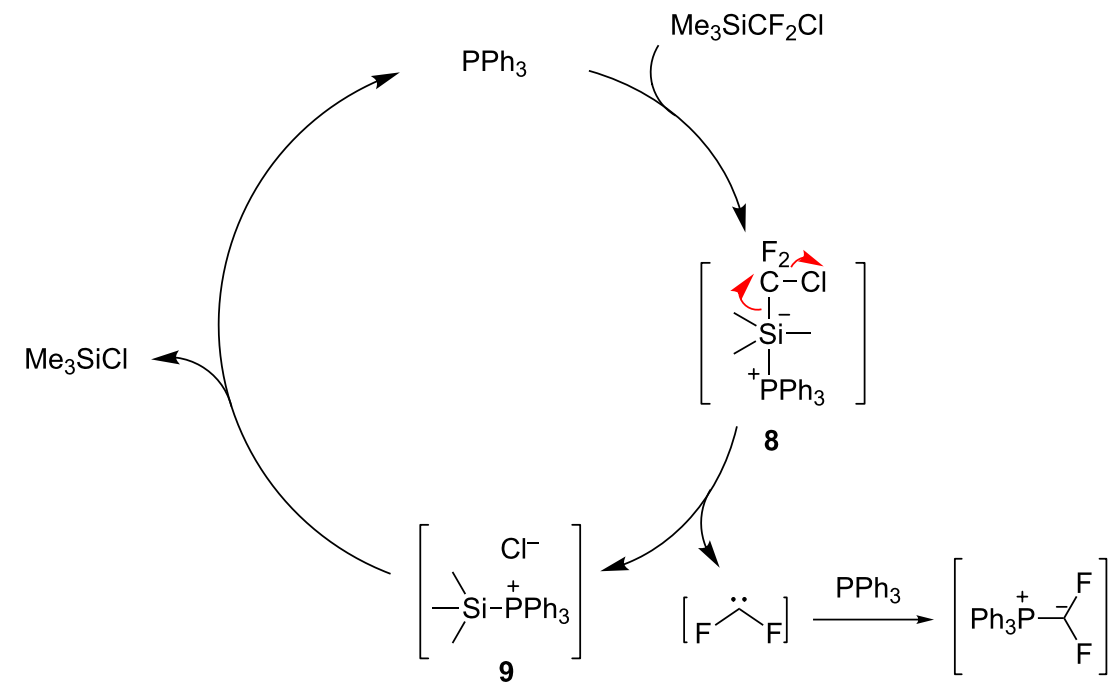

Path B:

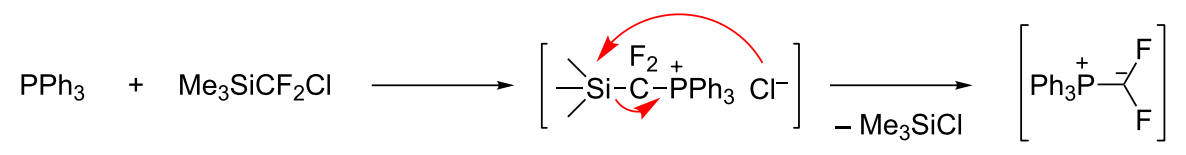

10 
substituent of $\mathrm{TMSCF}_{2} \mathrm{X}$ can influence the reactivity of these fluorinated silanes in difluoromethylene transfer reactions. Further research on the synthetic application of $\mathrm{TMSCF}_{2} \mathrm{X}$ $(\mathrm{X}=\mathrm{F}, \mathrm{Cl}$, and $\mathrm{Br})$ is currently underway.

\section{Supporting Information}

Full experimental details (difluoromethylation of $O, S$, and $\mathrm{N}$-nucleophiles and gem-difluoroolefination of carbonyl compounds with $\mathrm{TMSCF}_{2} \mathrm{Cl}$ ) and compound characterization data are given.

\section{Supporting Information File 1}

Experimental procedures and characterization data. [http://www.beilstein-journals.org/bjoc/content/ supplementary/1860-5397-10-32-S1.pdf]

\section{Acknowledgements}

Support of our work by the National Basic Research Program of China (2012CB821600 and 2012CB215500) the National Natural Science Foundation of China (20825209 and 21202189), and the Chinese Academy of Sciences is gratefully acknowledged.

\section{References}

1. Chambers, R. D. Fluorine in Organic Chemistry; Blackwell: Oxford, 2004.

2. Bégué, J.-P.; Bonnet-Delpon, D. Bioorganic and Medicinal Chemistry of Fluorine; John Wiley and Sons: Hoboken, 2008.

3. Kirsch, P. Modern Fluoroorganic Chemistry: Synthesis, Reactivity, Applications, 2nd ed.; Wiley-VCH: Weinheim, 2013.

4. McDonald, I. A.; Lacoste, J. M.; Bey, P.; Palfreyman, M. G.; Zreika, M. J. Med. Chem. 1985, 28, 186-193. doi:10.1021/jm00380a007

5. Altenburger, J.-M.; Lassalle, G. Y.; Matrougui, M.; Galtier, D.; Jetha, J.-C.; Bocskei, Z.; Berry, C. N.; Lunven, C.; Lorrain, J.; Herault, J.-P.; Schaeffer, P.; O'Connor, S. E.; Herbert, J.-M. Bioorg. Med. Chem. 2004, 12, 1713-1730. doi:10.1016/j.bmc.2004.01.016

6. Weintraub, P. M.; Holland, A. K.; Gates, C. A.; Moore, W. R.; Resvick, R. J.; Bey, P.; Peet, N. P. Bioorg. Med. Chem. 2003, 11, 427-431. doi:10.1016/S0968-0896(02)00434-0

7. Blackburn, G. M.; England, D. A.; Kolkmann, F. J. Chem. Soc., Chem. Commun. 1981, 930-932. doi:10.1039/C39810000930

8. Lapierre, J.; Ahmed, V.; Chen, M.-J.; Ispahany, M.; Guillemette, J. G.; Taylor, S. D. Bioorg. Med. Chem. Lett. 2004, 14, 151-155. doi:10.1016/j.bmcl.2003.09.089

9. Navidpour, L.; Lu, W.; Taylor, S. D. Org. Lett. 2006, 8, 5617-5620. doi:10.1021/ol062357z

10. Motherwell, W. B.; Tozer, M. J.; Ross, B. C. J. Chem. Soc., Chem. Commun. 1989, 1437-1439. doi:10.1039/C39890001437

11. Chambers, R. D.; Vaughan, J. F. S. Top. Curr. Chem. 1997, 192, 1-38. doi:10.1007/BFb0119264
12. Nguyen, B. V.; Burton, D. J. J. Org. Chem. 1997, 62, 7758-7764. doi:10.1021/jo971019w

13. Hayashi, S.-i.; Nakai, T.; Ichikawa, N.; Burton, D. J.; Naae, D. G.; Kesling, H. S. Chem. Lett. 1979, 8, 983-986. doi:10.1246/cl.1979.983

14. Ichikawa, J.; Wada, Y.; Okauchi, T.; Minami, T. Chem. Commun. 1997, 1537-1538. doi:10.1039/A703110F

15. Yokota, M.; Fujita, D.; Ichikawa, J. Org. Lett. 2007, 9, 4639-4642. doi:10.1021/ol702279w

16. Hayashi, S.-i.; Nakai, T.; Ishikawa, N. Chem. Lett. 1980, 9, 651-654. doi:10.1246/cl.1980.651

17. Chelucci, G. Chem. Rev. 2012, 112, 1344-1462. doi:10.1021/cr200165q

18. Liu, Y.; Deng, M.; Zhang, Z.; Ding, X.; Dai, Z.; Guan, J. Chin. J. Org. Chem. 2012, 32, 661-666. doi:10.6023/cjoc1104113

19. Fuqua, S. A.; Duncan, W. G.; Silverstein, R. M. Tetrahedron Lett. 1964, 5, 1461-1463. doi:10.1016/S0040-4039(01)89512-5

20. Herkes, F. E.; Burton, D. J. J. Org. Chem. 1967, 32, 1311-1318. doi:10.1021/jo01280a007

21. Zheng, J.; Cai, J.; Lin, J.-H.; Guo, Y.; Xiao, J.-C. Chem. Commun. 2013, 49, 7513-7515. doi:10.1039/C3CC44271C

22. Naae, D. G.; Burton, D. J. J. Fluorine Chem. 1971, 1, 123-125. doi:10.1016/S0022-1139(00)82541-5

23. Naae, D. G.; Burton, D. J. Synth. Commun. 1973, 3, 197-200. doi:10.1080/00397917308062035

24. Nowak, I.; Robins, J. M. Org. Lett. 2005, 7, 721-724. doi:10.1021/ol047416s

25. Thomoson, C. S.; Martinez, H.; Dolbier, W. R., Jr. J. Fluorine Chem. 2013, 150, 53-59. doi:10.1016/j.jluchem.2013.02.026

26. Zheng, J.; Lin, J.-H.; Cai, J.; Xiao, J.-C. Chem.-Eur. J. 2013, 19, 15261-15266. doi:10.1002/chem.201303248

This article appeared online after our submission of this article. It is a paper describing the deoxygenative gem-difluoroolefination of carbonyl compounds with the difluorocarbene/phosphine procedures, i.e. $\mathrm{HCF}_{2} \mathrm{Cl} /$ propylene epoxide $/ n-\mathrm{Bu}_{4} \mathrm{NCl}$ (cat.) $/ \mathrm{Ph}_{3} \mathrm{P}$.; $\mathrm{FSO}_{2} \mathrm{CF}_{2} \mathrm{CO}_{2} \mathrm{TMS} / \mathrm{NaF}$ (cat.)/Ph ${ }_{3} \mathrm{P}$.

27. Zhang, L.; Zheng, J.; Hu, J. J. Org. Chem. 2006, 71, 9845-9848. doi:10.1021/jo061799l

28. Zheng, J.; Li, Y.; Zhang, L.; Hu, J.; Meuzelaar, G. J.; Federsel, H.-J. Chem. Commun. 2007, 5149-5151. doi:10.1039/B713156A

29. Zhang, W.; Wang, F.; Hu, J. Org. Lett. 2009, 11, 2109-2112. doi:10.1021/ol900567c

30. Wang, F.; Huang, W.; Hu, J. Chin. J. Chem. 2011, 29, 2717-2721. doi:10.1002/cjoc.201100325

31. Wang, F.; Zhang, W.; Zhu, J.; Li, H.; Huang, K.-W.; Hu, J. Chem. Commun. 2011, 47, 2411-2413. doi:10.1039/c0cc04548a

32. For preliminary results on the difluoromethylation of $O, S$, and $\mathrm{N}$-nucleophiles with $\mathrm{TMSCF}_{2} \mathrm{Cl}$ under aqueous basic conditions, see Supporting Information File 1.

33. Wang, F.; Luo, T.; Hu, J.; Wang, Y.; Krishnan, H. S.; Jog, P. V.; Ganesh, S. K.; Prakash, G. K. S.; Olah, G. A. Angew. Chem., Int. Ed. 2011, 50, 7153-7157. doi:10.1002/anie.201101691

34. Li, L.; Wang, F.; Ni, C.; Hu, J. Angew. Chem., Int. Ed. 2013, 52, 12390-12394. doi:10.1002/anie.201306703

35. Ruppert, I.; Schlich, K.; Volbach, W. Tetrahedron Lett. 1984, 25 , 2195-2198. doi:10.1016/S0040-4039(01)80208-2

36. Broicher, V.; Geffken, D. J. Organomet. Chem. 1990, 381, 315-320. doi:10.1016/0022-328X(90)80061-4

37. Yudin, A. K.; Prakash, G. K. S.; Deffieux, D.; Bradley, M.; Bau, R.; Olah, G. A. J. Am. Chem. Soc. 1997, 119, 1572-1581. doi:10.1021/ja962990n 
38. Prakash, G. K. S.; Hu, J.; Olah, G. A. J. Org. Chem. 2003, 68, 4457-4463. doi:10.1021/jo030110z

39. Prakash, G. K. S.; Jog, P. V.; Batamack, P. T. D.; Olah, G. A. Science 2012, 338, 1324-1327. doi:10.1126/science.1227859

40. Kosobokov, M. D.; Dilman, A. D.; Levin, V. V.; Struchkova, M. I. J. Org. Chem. 2012, 77, 5850-5855. doi:10.1021/jo301094b

41. Matsukawa, S.; Saijo, M. Tetrahedron Lett. 2008, 49, 4655-4657. doi:10.1016/j.tetlet.2008.05.053

42. Miller, N. E. J. Am. Chem. Soc. 1965, 87, 390-391. doi:10.1021/ja01080a049

43. McNulty, J.; Das, P. Chem.-Eur. J. 2008, 14, 8469-8472. doi:10.1002/chem.200801358

\section{License and Terms}

This is an Open Access article under the terms of the Creative Commons Attribution License

(http://creativecommons.org/licenses/by/2.0), which permits unrestricted use, distribution, and reproduction in any medium, provided the original work is properly cited.

The license is subject to the Beilstein Journal of Organic Chemistry terms and conditions:

(http://www.beilstein-journals.org/bjoc)

The definitive version of this article is the electronic one which can be found at: doi:10.3762/bjoc. 10.32 